\title{
CRITICAL READING FOR SELF-CRITICAL WRITING
}

\section{Ida Royani, Heni Arwida}

IAIN Padangsidimpuan, Sumatera Utara, Indonesia

Email: royanii381@gmai.com, heniarwida@gmail.com

\begin{abstract}
This study aims at exploring students' critical reading strategies and explaining how their critical reading encounters critical writing. It is due to students were lack of confidence in their ability to challenge the arguments and evidence put forward by respected academics author. The qualitative design was established by Gay and Airasian (2012) by delivering open and closed ended questions through Google forms and analyzing corpus based on students' proposal text. Then, it had been analyzed by using cyclical steps; reading, describing, clarifying and interpreting. Based on the data, firstly, it has been revealed that students' critical reading strategies mostly established are making connections, contextualizing and making applications and identifying problems and creating annotations. Students were rarely to challenge author's assumptions, translate ideas into visuals and evaluate arguments. Secondly, their reading activity also reflected their critical reading, in other words, students state their purpose of writing, define key terms, and manage references on their work. Based on this, it can be figured out that students' critical writing were relied on superficial argument development and format-based writing which performed a shallow writing.
\end{abstract}

Keywords: academic text, critical reading strategy, critical writing

Received: 2021-10-20; Accepted: 2021-11-05; Published: 2021-11-20

\section{Introduction}

One of the important skills for students at the final step of graduation is writing academic text, an activity to produce a writing for scholar recognition as the requirement to acquire certain degree. It is also an ability in which involving together the human accuracy to reach adequate resources and references to constructing the concept of knowledge and a depth of interpretation to be written. So that, writing can be established to compose arguments by a well-organized paragraph.

However, it could be unrealized that, primarily, assembling any relevant studies, literatures, and reviews is what actually processed far away before transferring ideas into paragraphs and pages. At the beginning, searching notation which is usable to be cited and paraphrased, a future author will select consciously what a matter of fact of what is heading off to ideas development. Directing of writing purposes can only be provided by offering a complexity of reading sources and comprehension which in

$\begin{array}{ll}\text { How to cite: } & \text { Royani. I., Arwida., H. (2021) Critical Reading for Self-Critical Writing. Syntax Literate: Jurnal Ilmiah } \\ & \text { Indonesia, 6(2) } \\ \text { E-ISSN: } & \text { 2548-1398 } \\ \text { Published by: } & \text { Ridwan Institute }\end{array}$


hence may offer a preview roadmap what should be inscribe down concisely. As a result, sufficient references which have been read contribute mostly to this initial sequence of writing academic text.

Concerning with this earlier step, reading all about what should be written is a must. A future author has to be equipped him/ herself to gather tools in fabricating comprehension; including strategy. This is necessarily essential since reading word by word will be time consuming and less of comprehension and does not provide ability to describe higher order thinking for analysis and valuing which are quite dominant aspects for developing paragraph. In other words, critical reading for self- writing arises forward. Strategy in critical reading offers satisfactory step-by-step reading activity to overcoming precise comprehension for writing.

It is happening in which students' academic writing occurs without passing the critical reading steps initially. Writing activity is faced as a dichotomous skill which implies that opinion is rearranged with a low reading boundary. Students are engaging to the text they use for reviewing literature despite less of comprehension. Students may unintentionally copy what they read and use some additional entries as the reason they do not pasting the argument. As a result, plagiarism cannot be avoided.

Critical Reading Strategies (CRSs) helps the readers understanding how the authors develop their argument, so that future author is assisted with building ideas clearly. Moreover, CRSs will question a future author whether there is sufficient backing for the generalizations which avoid him/her making sweeping generalization in the writing which cannot justify to the reader. Also, CRSs is responsible to identify the main claims the authors make in putting forward their argument which in turns useful for future author to state the claims clearly for helping the readers understand the argument. In other words, being critical reader connects to a critical writer each other.

Students are also lack of confidence in their ability to challenge the arguments and evidence put forward by respected academics author. There is a frequent difficulty in justifying why a certain opinion is worth holding and in coping with challenging to their views. Many of students are unsure what is involved in being critical but are unwilling to say so because they assume that they are expected already know. These are some of views what actually occurs to the individual future authors at the beginning step of reconstructing ideas to their writing. In other words, it will have to be critical in reading from the point where it is begun preparing to write an academic writing.

That is why, exploration to the students' critical reading and how it is used by students to writing are definitely essential. To have a clear direction, the present study states the research questions as follows.

1. What are the students' critical reading strategies in writing academic text (thesis)?

2. How do students use the critical reading for their writing? 


\section{Literature Review}

\section{Critical Reading Strategies}

Critical reading is the process of constructing meaning of the text that is emerged by thinking critically. It clarifies that reading is not only the activity to understand the given text initially but also it builds a meta-interaction between author and reader to involve together in the text by understanding clues and tone before extracting the meaning (Diman et al., 2020). In other words, critical reading states an idea that while reading ones has to arrive at the situation where author occurs in the text.

Critical reading is also defined as active, careful, reflective, and analytic reading activity as cited by Kurland, 2000 in (Munawaroh, 2013). It ensures that readers are active asking questions, looking for facts, and suspending judgment (Damaianti et al., 2017) and (Suzanne, 2016). Interaction between reader and author is involved mutually and reflecting understanding each other. As it is also stated that reading critically is an essential part of reading proficiency (Rohmah, 2018).

Another argument about reading critically is that critical reading is the highest level of reading comprehension (Femilia, 2018). Reading the concept of knowledge is enabling readers to react to the ideas throughout the text (Quang \& Tran, 2017). It activates affective and intellectuality of readers to evaluate the author positions on the text that suits to the experience of readers. The more critical the readers towards the text, the more creative the readers to interpret the meaning of the authors.

Tendency to explore the students' critical reading was established by Arifin which revealed that there was significant differences in the critical reading skills between experimental and non-experimental students. More specifically, the differences are in determining the main idea, determining the purpose, making an inference, and taking the conclusion of the texts in the reading test. He argued that reading critically is crucial and important as this skill is powerful to affect the students' critical thinking, and hence for self-critical writing, (Arifin, 2020), (Par, 2018) and (Khonamri \& Karimabadi, 2015)

Reading critically is also a marked activity which requires the reader's understanding beyond the common approaches to read (Sari et al., 2012). It means that reading should depart to the position where readers depart to the point s/he comes originally and interact to the text without absorbing purely what presented in the text. Readers critically engage what actually the author meant and interpreted by showing critical thinking to give value and judge (Nasrollahi et al., 2015). Where the reading critically established is the place where critical thinking is used towards the text read. That is why, critical thinking is crucial to the learning process, cognitive development, and effective information seeking, specifically in the reading text. Critical reading has a significant place in the individual intellectual life, including reading skill. (Aghajani \& Gholamrezapour, 2019) and (Koray \& Çetinkılıç, 2020).

Kadir (2014) reveals that it is essential to teach the critical reading skill to students which in hope it will develop them to be critical thinkers. As it has recognized that being critical reader leads to be critical thinkers (Kadir et al., 2014). Never rejected that learners are quite important to sharpen their abilities to critically think whatever they receive whether it is text or discourse to listen.

Critical reading based on (Tomasek, 2009) is a stimuli to reach a reader interaction to the author in which it is useful to encourage the position of the readers with the text. He actually said that there are six prompts to be organized: 

a. Identification of problem or issue,
b. Making connections,
c. Interpretation of evidence,
d. Challenging assumptions,
e. Making applications, and
f. Taking a different point-of-view.

Critical reading goes beyond basic understanding and requires more strategies (Amalia, 2016), such as:
a. Understanding an author's ideas even if they are not stated directly
b. Recognizing patterns of organization in what you read
c. Using a questioning technique before, during, and after you read
d. Prioritizing an author's ideas
e. Translating an author's ideas into visuals
f. Identifying and evaluating an author's arguments
g. Creating new ideas using an author's ideas established by:

Additionally, the critical reading strategies in brief are also sequentially

1. Annotate: making note or marking the text, high light, underline

2. Preview: screening the text, overview, and read overall to generalize

3. Contextualize: making connections with existed ideas, activating background knowledge

4. Question: delivering critical questions and finding out answer throughout the text

5. Evaluate an Argument: judging, making decisions, valuing the ideas

6. Compare and Contrast: figuring out similarities, and differences across arguments to relevant works

The readers' response to the categories could be varied in many ways and hence those are actively helping readers understand the printed text and individually a frontier to confidently arouse a self-learning. This is actually what critical reading proposing to be established, reading by thinking. While a person reads throughout the text and follow the route provided, judging and valuing, concluding and understand the intended meaning of the author's thought, there s/he is critically reading indeed.

\section{Critical Reading for Self-Critical Writing}

There is (Sari et al., 2012) who argued that having good reading will help the students have good writing. It seems to be un-dichotomous that reading will contribute to ability to write. The more critical the readers, the more critical the writer writes the text. That is why, critical reading has its counterpart in self-critical writing (Goodwyn \& Stables, 2012). The following table shows their links together. 
Table 1

\section{Critical reading links to critical writing}

As a critical reader of the literature

As a self-critical writer of academic text

- Consider the authors' purpose in writing the account.

State your purpose in what you write to make it clear to your readers.

- Examine the structure of the account to help you understand how the authors develop their argument.

- Seek to identify the main claims the authors make in putting forward their argument.

- Adopt to skeptical stance towards the authors' claims, checking whether they support convincingly what they assert

- Question whether the authors have sufficient backing for the generalizations they make.

- Create a logical structure for your account that assists you with developing your argument, and make it clear to your readers.

- State your own main claims clearly to help your readers understand your argument.

- Assume what your readers adopt a skeptical stance to your work, so you must convince them by supporting your claims as far as possible.

- Check what the authors mean by key terms in the account and whether they use these terms consistently.

- Consider whether and how any values guiding the author's work may affect what they claim.

- Distinguish between respecting the authors as people and being skeptical about what they read.

- Keep an open mind, retaining a conditional willingness to be convinced.

- Check that everything the authors have written is relevant to their purpose in writing the account and the argument they develop.

- Expect to be given the information that is needed for you to be in a position to check any other literature sources to which the authors refer.

- Avoid make sweeping generalization in your writing which you cannot justify to your readers.

- Define the key terms you employ in your account so that your readers are clear what you mean, and use these terms consistently.

- Make explicit any values that guide what you write.

- Avoid attacking authors as people but are skeptical about what they write.

Assume that your readers are openminded about your work and are willing to be convinced if you can adequately support your claims

- Sustain your focus throughout your account, and avoid irrelevancies and digressions in what you write.

- Ensure that your referencing in the text and the reference list is complete and accurate so that your readers are in a position to check your sources.

\section{Methodology}

The present study used qualitative design to gain the answers of research questions. Qualitative research design is useful to describe and answer questions about particular, localized occurrence or context and the perspective of participant group toward events, beliefs and practices (Gay et al., 2012). The participants are the 24 students who are ongoing to write a thesis at the final semester and who are engaging and involving more frequently to the literatures which are accomplished on the thesis writing. They are selected by purposively convenience sampling strategy. 
The data were collected using questionnaire developed by theories provided on the literature. There were lists of questions to be responded by participants. Questions are open and closed- ended which are constructed by confirming to the theories used in the study of critical reading for self- critical writing and responses are recorded in the Google form nearly. Then, students' critical writing corpus was caught by their proposal text that that been examined.

The steps for analyzing qualitative data are processed cyclically. The analysis requires four iterative steps: reading/ memoing, describing, classifying and interpreting. Typically, the process of analysis focuses on (1) becoming familiar with the data and identifying main themes in it (reading/ memoing), (2) examining the data in depth to provide detailed descriptions of the setting, participants, and activities (describing), (3) categorizing and coding pieces of data and physically grouping them into themes (classifying), (4) interpreting and synthesizing the organized data into general conclusions or understanding (interpreting).

\section{Discussion}

\section{Students' Critical Reading Strategies}

Based on the data, students are describing their critical reading strategies by following the steps as in the following.

\section{Identification of problem or issue}

Students were asked on the identification of problem or issue by clarifying the authors' purpose of writing. Based on the data, there had been revealed that most of students were confirmed that they identified the author's aim on the book they cited. Students are generally established identifying the problems that being accounted for. However, students cannot clarify those purposes correctly. They just claimed that the purpose of writing is the overview of the book focuses and it leads to assume that was it, author's purpose of writing. They cannot recognize who the problem related to, what complexities of it and sources of the issue addressed as activities to identifying issues. Yet, it implies that students realized awareness of doing a starting point of critical reading even only a little of them appropriately find accurate author's purposes.

\section{Making connections}

Students were asked about their built connections to the text they read. Students are completely linking their previous knowledge with the argument provided on the text. It is assumed that when they are writing their proposals, they are beholden to perform literature they expected to be useful for analysis. That is why, all the respondents are delivering initial questions to lead them reading through the text.

\section{Interpretation of evidence}

Students were asked about their interpretation of the text they read. Only a few of them did not use this activity. They stated that author's ideas and opinions on the text had been read without interpreting any relevant facts for their belief approval. Meanwhile, most of them convinced that they figured out what evidence and facts delivered on the text as they used for their writing. Even if this activity was done not in 
complexity, demonstrating how critical students to think of fact on text is accepted to be appreciated.

\section{Challenging assumptions}

Students were questioned about their way of challenging assumptions. Students were confirmed that they have limited manner to encounter conventions on the text while reading. Most of students thought about their need of facts to be written and not focus to get exciting considering more about what author's ideas. Observing facts and evidence as the source for writing is what actually students bear in mind while reading a text. Focusing on what suitable information to fill the gap of what their interest to write is being more essential than that of challenging assumptions of the text.

\section{Making applications}

Students were required to answer how the text will be practical to their mind by relating ideas which have previously been conceptualized before. Almost all of students argued that they synchronized their reading text to response what they have known. This activity offers students an opportunity to understand faster since they reacted what was in their mind. That is why, students can value the reading text to be useful to what they need as a source for their writing.

\section{Taking a different point-of-view}

Students were needed to response to the text they read by taking a different point of view. They answered that different point of view is a manner of adding evidence to the fact that they are looking for. Distinguishing various opinions to be interpreted is established by assigning relevant opinion as a media for comparisons.

Overall, students used critical reading strategies proposed by Tomasek (2009) with average proportion. Based on the six strategies, most of the prompts are equal to appear when they are reading and only one strategy was used limitedly. According to the most of students, they were identifying the problem or issue, making connections, interpreting evidence, making applications and taking a different point of view. Unfortunately, a few of students were challenging the assumption. The following chart demonstrates the used strategies. 


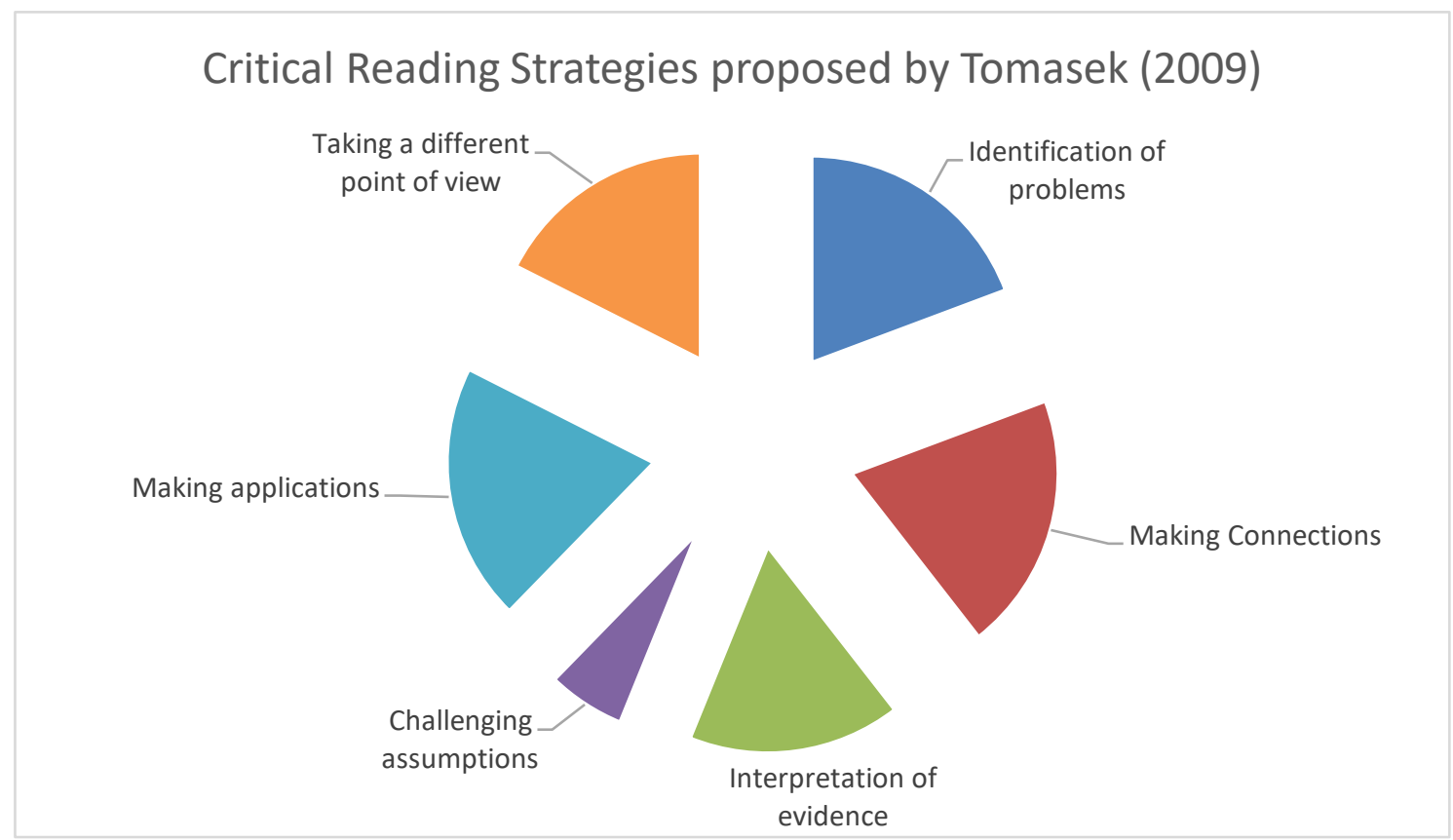

Figure 1

\section{Students' Critical Reading Strategies 1}

Moreover, students' critical reading strategies were also considered by looking at the following chart. There were seven strategies proposed by Amalia (2016) which also responded by students. Overall, students were using critical reading strategies; namely understanding the author's ideas even if they are not stated directly, recognizing patterns of organization in what they read, using a questioning technique before, during, and after they read, prioritizing the author's ideas, identifying and evaluating an author's arguments and creating new ideas using an author's ideas. A small activity was conducted by students was translating the author's ideas into visuals. 
Ida Royani, Heni Arwida

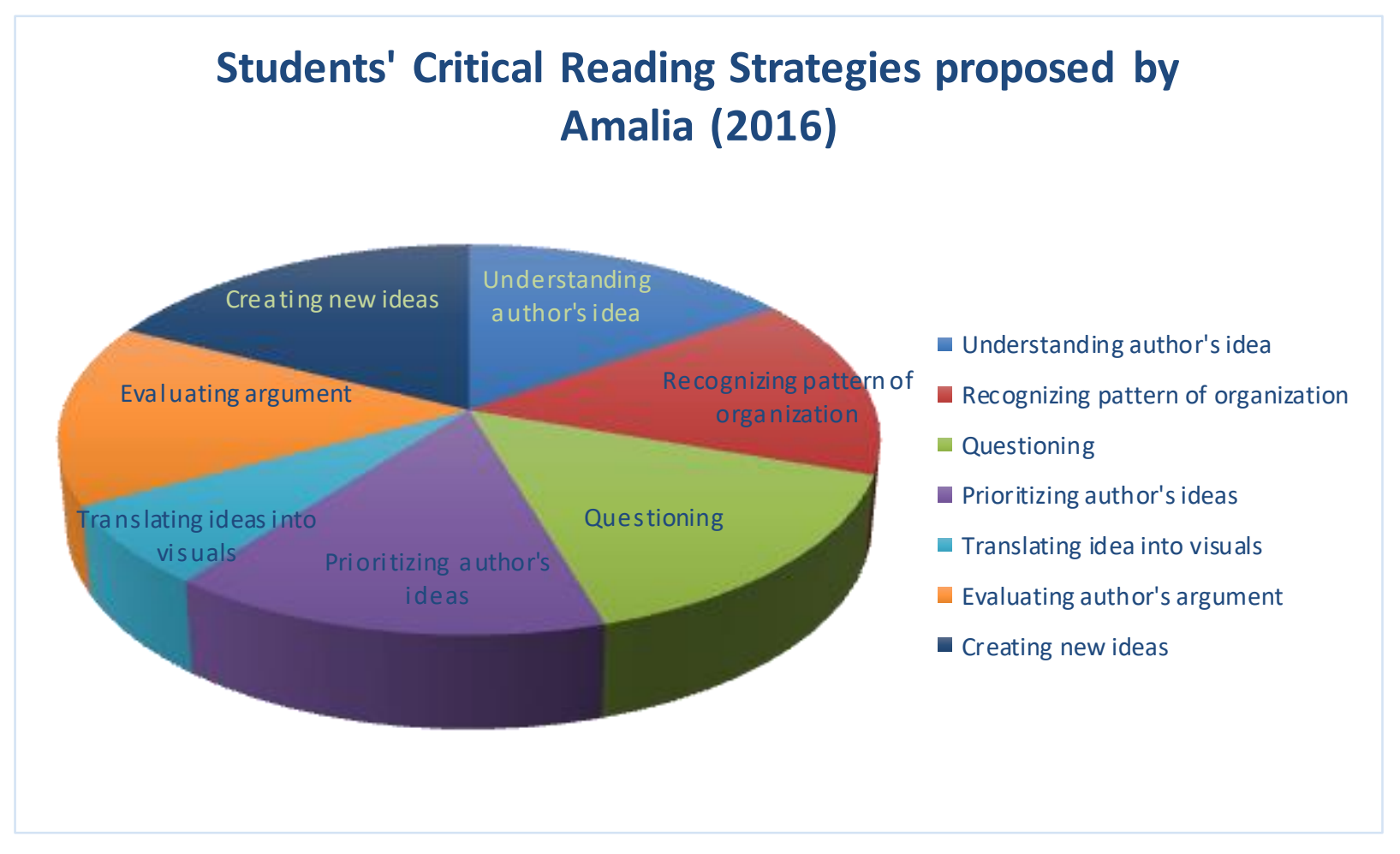

Figure 2

Students' Critical Reading Strategies 2

Technically, critical reading strategies that can be established by following the sequential steps used by students proposed by Amalia (2016). The following chart demonstrates the proportion of the critical reading strategies conducted by students overall. 


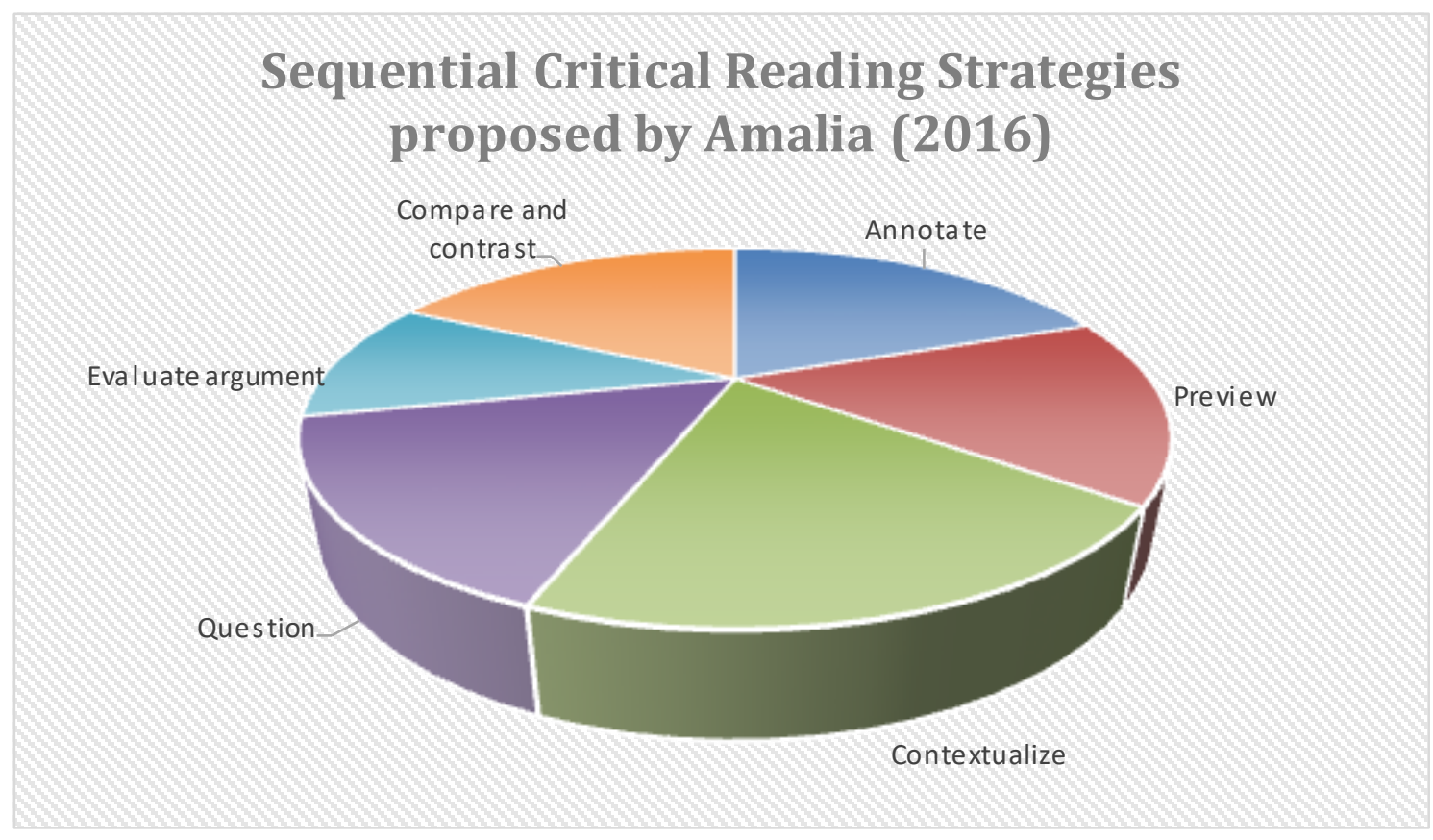

Figure 3

\section{Annotate}

\section{Sequential Critical Reading Strategies}

Students were convinced that they used annotation while they reading. Such activity can be underline key words, important information, highlight, note taking and so forth. By this way, students are quicker finding important arguments.

\section{Preview}

Students stated that they review the content of the book previously before jumping to the information they need. By looking at the cover, table of content and subheadings, students can immediately find what they are searching for.

\section{Contextualize}

Students responded that they have ensured the book authors they have to read were eligible to them and valuable to support what they need to find. Biography is essential to notice that the authors are ideals to refer. Most of the books they read are written by who were familiar with them during their learning process before and books had been advised by lecturers.

\section{Question}

Students initially read the text by delivering questions to lead them reading faster and quicker. Finding arguments and ideas is originated from the question, "What arguments are my concerns and am I looking for?" Most of respondents were unconsciously delivering questions, yet they aware of the questions they need to find the answer through the text.

\section{Evaluate an Argument}

Students stated that they appraised the authors' arguments. However, by deeper elicitation to the response, it was found that students cannot examine the authors' idea 
which makes their understanding on the text becoming accepting anything that authors have written. It can be described by having less of analysis on the claims and support that provided by authors on their account. The students cannot find any supports such as assumptions to impact their understanding on the text. Students are lack of tendency to look for authors' point of views. Unfortunately, even if they convinced they evaluated the author's argument, indeed students were not examining the authors' opinions and thoughts.

\section{Compare and Contrast}

Students indicated that they compare and contrast the opinions they read to other relevant arguments. They explored related studies to seek similarities and differences among the ideas throughout the text, as a result students understand text better.

In general view on the use of critical reading strategies conducted by students, there are making connection, contextualizing and making application frequently contribute to them mostly while they are reading. Subsequently, students used annotation and identification of problem to start their reading. Continuously, students are understanding the ideas, contrasting and comparing, interpreting evidence, taking different point of view, creating new ideas, recognizing pattern of organization, questioning, previewing and evaluate the arguments. Last of all, students are rarely to conduct challenging arguments and translating ideas into visuals. The following figure presents the number of respondents using those critical reading strategies.

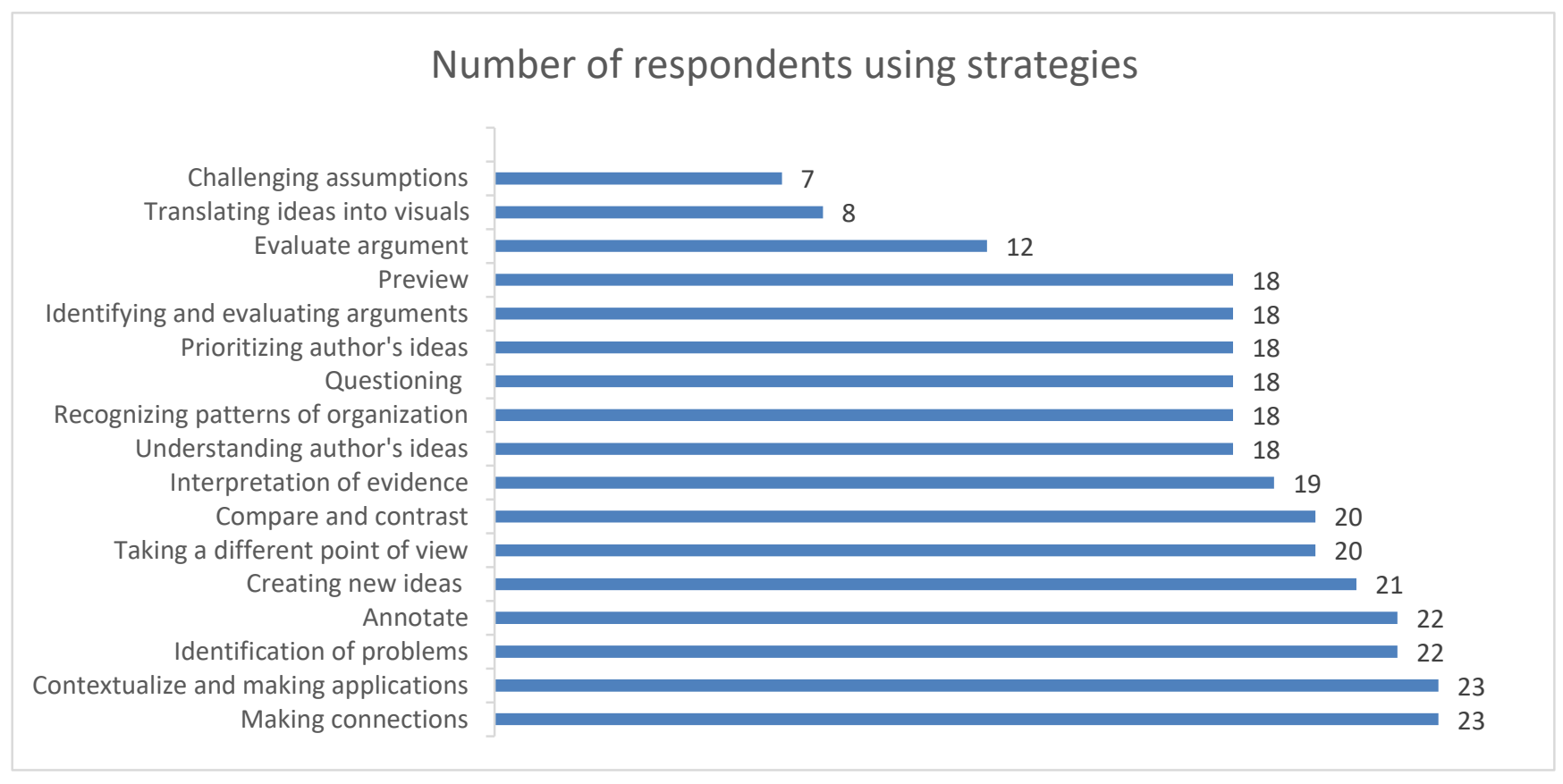

Figure 4

Number of Respondents Using Strategies 


\section{Indication of critical reader for critical writer}

Based on Goodwyn and Stable (2012), as a critical reader of the literature, students are indicated by critically judge the work of writing as seen in the following table.

Table 2

Students' Responses on the Critical Reader Indicators

\begin{tabular}{|c|c|c|c|}
\hline No & Critical Reader Indicators & Responses & Students' responses \\
\hline 1 & $\begin{array}{l}\text { Considering the purpose of } \\
\text { writer }\end{array}$ & V & $\begin{array}{l}\text { Students considered the author's purposes } \\
\text { and had explanation to it. }\end{array}$ \\
\hline 2 & $\begin{array}{l}\text { Examining the structure } \\
\text { of the writing to develop } \\
\text { argument }\end{array}$ & $\mathrm{X}$ & $\begin{array}{l}\text { Students had no specific explanation on } \\
\text { how the arguments were developed }\end{array}$ \\
\hline 3 & $\begin{array}{l}\text { Identifying the authors' main } \\
\text { claims }\end{array}$ & $\mathrm{X}$ & $\begin{array}{l}\text { Students did not find the main claim od the } \\
\text { writer }\end{array}$ \\
\hline 4 & Adopting skeptical stance & $\mathrm{X}$ & $\begin{array}{l}\text { Students dominantly believed in what } \\
\text { writer argued. }\end{array}$ \\
\hline 5 & $\begin{array}{l}\text { Questioning on sufficient } \\
\text { backing claims }\end{array}$ & $\mathrm{X}$ & $\begin{array}{l}\text { Students did not ask for supporting backing } \\
\text { claims for generalization }\end{array}$ \\
\hline 6 & $\begin{array}{l}\text { Checking the key terms and } \\
\text { consistency }\end{array}$ & V & $\begin{array}{l}\text { Students stated that key terms were defined } \\
\text { accurately and those had been used } \\
\text { consistently }\end{array}$ \\
\hline 7 & $\begin{array}{l}\text { Making explicit values that } \\
\text { affect the claim }\end{array}$ & $\mathrm{V}$ & $\begin{array}{l}\text { Students understood the values guiding the } \\
\text { authors' writing that influence the claims }\end{array}$ \\
\hline 8 & $\begin{array}{l}\text { Respecting between the } \\
\text { authors as people and about } \\
\text { skeptical }\end{array}$ & $\mathrm{V}$ & $\begin{array}{l}\text { Students distinguished between the author } \\
\text { as people and being skeptical about } \\
\text { argument }\end{array}$ \\
\hline 9 & $\begin{array}{l}\text { Checking relevancies of the } \\
\text { purpose to the argument } \\
\text { development }\end{array}$ & $\mathrm{V}$ & $\begin{array}{l}\text { Students were open-minded and stated that } \\
\text { arguments were relevance with other } \\
\text { sources/ works. Yet, argumentation that } \\
\text { was developed by authors cannot be } \\
\text { identified by students }\end{array}$ \\
\hline 10 & $\begin{array}{l}\text { Expecting given reference } \\
\text { completely }\end{array}$ & V & $\begin{array}{l}\text { Students expected to be provided by } \\
\text { complete references list and any other } \\
\text { literature sources }\end{array}$ \\
\hline
\end{tabular}

Based on the data, students indicated to be critical readers for several points which discovered students cannot be classified as critical reader completely while they are writing their thesis. Most of students did not know the main claim of the book writer they referred and hard to explain how the authors developed the argumentation. Moreover, students without thinking critically, received entirely what authors wrote and believed in it. So that, asking for supporting backing claims was not emerged.

However, students were dominantly indicating themselves to be critical readers. They identified the purposes of authors' writing, checked for defined key terms, understood the values of authors' writing, respected author as people and been skeptical, 
open minded to clarify supporting claims, and expected to have a list of references. Inclusively, students were critical in reading their book reference while writing their final academic manuscript although there had been absence of other indications.

\section{Use of Critical reading for Students' Self-Critical Writing}

Based on the students' responses on the critical reader indicators, students are expected to be critical writers. Students' work on writing academic text should be described as clear as possible to be observed their critical writing. To be critical writer, students should be noticed the following standards led by the critical reading marking points. Since it has been convinced that it is a way of linking together a critical approach on students' reading with their self-critical approach to their writing.

\section{Stating purpose}

Students were stating their writing purpose on their writing since the outline format of the thesis writing required of the research objectives. Most of the students were clearly directing the purpose to answer the research questions. None of them intentionally forgot to determine the intended aim on their works. Therefore, identifying the focus as their core issues should be certainly found in their writing.

\section{Creating logical structure to develop argument}

Developing argument with a logical structure can be revealed by understanding critically to the reference students cited. This logic should be examined and subsequently led students to assemble opinions which brings about to a clear explanation to the readers. Based on the students proposal account, students were found generally to offer ideas and theories related to their issues. Proposal chapter has been assumed to sufficiently position the ideas which were reviewed orderly according the important theory to be discussed. Advisory of the literature appropriateness selection should be appreciated which are highly contributive.

\section{Stating main claims}

Topic of the research should be stated as the main claims. Students are required to clarify what claims are delivered to ensure readers what assumptions and ideas that help encountered the research later. Students were using 'Background of the problem' section to convey the envisioned assertions. They used to obey the rule of paragraph organization i.e. inductive or deductive to overview a researchable problem. Investigating how the claims were navigated cannot be seen on the students account despite main claim statement have been revealed.

\section{Providing supporting claims}

Students have to be confident to their ability convincing their claim to their readers as researcher is the place they rely on their accounts. Being in doubt on the theories had made students provided supporting claims to their writing based on their experiences, observation or preliminary study. These ways have in turn arranged for backing the main claims for it exposed more detail to the field of the research focus.

\section{Avoiding sweeping generalization}


Research language is logic and reflecting thoughts. Students were responsible to assure their readers to escape emerging a sweeping generalization. It is what academic writing should concern with. Based on the students' works, getting away from this activity could be recognized by making sufficient backing for generalization when clarifying claims they had observed as phenomena. Giving a flow of writing currently on their writing could be seen surficial, yet an effort to avoid reader's overthinking can be accepted.

\section{Defining key terms and using them consistently}

Terminologies were defined strongly and used consistently. Research proposal format also marginalizes the key terms to be explained clearly as like those are meant by researcher. Students employed the terms where it should be stated and when it should be appeared. What means by key terms at the beginning of their uses, it is also the meaning of the terms entire the works. Consistently on the use of key terms was revealed in a whole students' proposals.

\section{Sustaining focus}

Claims are topic that research focuses on. Based on the students' works, the focus have been identified nourishing from the beginning to the last session. This reflects understanding that supporting backup have been demonstrated and students were being assisted through their account of writing. Conclusive ideas are willing to guarantee the focus to be on the right track surely.

\section{Completing the reference list}

Reference list should be accurate and complete with the text students referencing. Most of the students were using digital application to manage the reference list and citation. There is no doubt to clearly find that students have thoroughly listed resources they applied. A clear presentation of the students' critical writing on their proposals can be seen in the following table.

Table 3

Critical Writing on the Students' Works

\begin{tabular}{|c|c|c|}
\hline No. & Criteria & Students' work \\
\hline 1. & Stating purpose & Clear statement of purposes \\
\hline 2. & $\begin{array}{l}\text { Creating logical structure to } \\
\text { develop argument }\end{array}$ & $\begin{array}{l}\text { Logic organization based on title, but less of use } \\
\text { to argument development }\end{array}$ \\
\hline 3. & Stating main claims & Clarification of the problem and issue \\
\hline 4. & Providing supporting claims & $\begin{array}{l}\text { Phenomena, experience, observation, } \\
\text { preliminary study }\end{array}$ \\
\hline 5. & $\begin{array}{l}\text { Avoiding } \\
\text { generalization }\end{array}$ & Describing phenomena, but superficial \\
\hline 6. & $\begin{array}{l}\text { Defining key terms and using } \\
\text { them consistently }\end{array}$ & Definitions occur and found repeatedly \\
\hline 7. & Sustaining focus & One focus is all the work concerns \\
\hline 8. & Completing the reference list & $\begin{array}{l}\text { Reference manager and citation (Zotero and } \\
\text { Mendeley) }\end{array}$ \\
\hline
\end{tabular}




\section{Conclusion}

Students' critical reading strategies dominantly used making connections and contextualization and making applications, identification of problems or issues and annotation. Students argued that they synchronized their reading text to response what they have known about the text, activating their prior knowledge on the text and subsequently understanding the text problems or issues to be claimed. To support their activities, students are likely to give annotations on what they read by highlighting, heading, underline, and so forth to differentiate what they need from what they should be less to focus.

By clarifying the way students criticized the text they used on their academic writing, students were also in condition to be a critical writers. It is worthwhile because their future writing will be declaimed by other people relevant to their works. According to this point of view, students committed that they state their problems clearly by emphasize their experience, pre-observation, and explaining phenomena. Students were also defining key terms obviously and consistently used, managing references and arguing purposes of writing. Those were conducted by keeping up academic writing format which explicitly accompanying writer to write based on order. However, to those things which are implicitly established, such as developing arguments, values, generalization manner, structure of opinions were presented faintly vague and uncertain to confirm. This condition also linked to students' critical reading ways where they did not reveal any author's logical structure of arguments, organization of claims and being trusted with the stance of claims. Therefore, students' critical reading strategies also reflected to their critical writing.

\section{BIBLIOGRAPHY}

Aghajani, M., \& Gholamrezapour, E. (2019). Critical thinking skills, critical reading and foreign language reading anxiety in Iran context. International Journal of 
Instruction, 12(4), 219-238. https://doi.org/10.29333/iji.2019.12414a. Google Scholar

Amalia, I. (2016). Authentic Texts for Critical Reading Activities. The Journal of English Language Studies, 01(01), 35-44. Google Scholar

Arifin, S. (2020). The Role of Critical Reading to Promote Students' Critical Thinking and Reading Comprehension. Jurnal Pendidikan Dan Pengajaran, 53(3), 318. https://doi.org/10.23887/jpp.v53i3.29210. Google Scholar

Damaianti, V. S., Damaianti, L. F., \& Mulyati, Y. (2017). Cultural Literacy Based Critical Reading Teaching Material with Active Readerstrategy for Junior High School. International Journal of Evaluation and Research in Education (IJERE), 6(4), 312. https://doi.org/10.11591/ijere.v6i4.10775. Google Scholar

Diman, H., Jusnita, N., Dahlan, S., \& Daud, A. H. (2020). Students' Competence in $\begin{array}{llll}\text { Critical Reading. } & \text { Jurnal }\end{array}$ https://doi.org/10.33387/j.bilingual.v10i2.2735. Google Scholar

Femilia, P. S. (2018). Critical Reading Strategies Employed By Good Critical Readers of Graduate Students in Elt , State University of Malang. Tefla Journal, 1(1), 3034. http://repository.um.ac.id/id/eprint/58736. Google Scholar

Gay, L. R., Mills, G. E., \& Airasian, P. (2012). Competencies for Analysis and Applications 10th Edition. In Pearson Education, Inc (Vol. 6, Issue 2). http://library1.nida.ac.th/termpaper6/sd/2554/19755.pdf. Google Scholar

Goodwyn, A., \& Stables, A. (2012). Learning to Read Critically in Language and Literacy. In Learning to Read Critically in Language and Literacy. SAGE Publications, Ltd. https://doi.org/10.4135/9781849209410. Google Scholar

Kadir, N. A., Subki, R. N., Haneem, F., Jamal, A., \& Ismail, J. (2014). The Importance of Teaching Critical Reading Skills in a Malaysian Reading Classroom. The 2014 WEI International Academic Conference Proceedings, 208-219. https://www.westeastinstitute.com/wp-content/uploads/2014/06/Norbaiyah-AbdKadir-Full-Paper.pdf. Google Scholar

Khonamri, F., \& Karimabadi, M. (2015). Collaborative Strategic Reading and Critical Reading Ability of Intermediate Iranian Learners. Theory and Practice in Language Studies, 5(7), 1375. https://doi.org/10.17507/tpls.0507.09. Google Scholar

Koray, Ö., \& Çetink1lıç, S. (2020). The Use of Critical Reading in Understanding Scientific Texts on Academic Performance and Problem-solving Skills. Science Education International, 31(4), 400-409. https://doi.org/10.33828/sei.v31.i4.9. Google Scholar

Munawaroh, R. O. (2013). Implementing Critical Reading Tasks to Improve Reading 
Comprehension of The 11 th Grade Students of SMA N 3 Bantul. Universal Journal of Educational Research. Google Scholar

Nasrollahi, M. A., Krishnasamy, P. K. N., \& Noor, N. M. (2015). Process of implementing critical reading strategies in an Iranian EFL classroom: An action research. International Education Studies, 8(1), 9-16. https://doi.org/10.5539/ies.v8n1p9. Google Scholar

Par, L. (2018). The EFL Students' Critical Reading Skills across Cognitive Styles. Jeels, 148(1), 148-162. Google Scholar

Quang, T., \& Tran, N. (2017). Critical Reading: A Guidebook for Postgraduate Students. Hue University Publishing House, January 2015, 1-43. Google Scholar

Rohmah, G. N. (2018). Critical Reading: Students' Problems, Strategies, and Reflections. J-ELLiT (Journal of English Language, Literature, and Teaching), 2(1), 20. https://doi.org/10.17977/um046v2i1p20-24. Google Scholar

Sari, A. K., Drajati, N. A., \& Sarosa, T. (2012). the Case Study of the Implementation of Critical Reading. 12, 247-256. Google Scholar

Suzanne, N. (2016). Being Active Readers By Applying Critical Reading Technique. Ta'dib, 14(1). https://doi.org/10.31958/jt.v14i1.197. Google Scholar

Tomasek, T. (2009). Critical reading: Using reading prompts to promote active engagement with text. International Journal of Teaching and Learning in Higher Education, 21(1), 127-132. Google Scholar

\section{Copyright holder:}

Haerul Al Aziz, Mohammad Kemal Dermawan (2021)

First publication right:

Syntax Literate: Jurnal Ilmiah Indonesia

This article is licensed under:

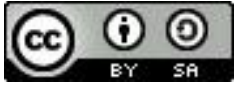

